\title{
Bacteriophage-resistant Mutants of Escherichia coli k12 with Altered Lipopolysaccharide. Studies with Concanavalin A
}

\author{
By R. N. PICKEN* AND I. R. BEACHAM $†$ \\ Department of Botany and Microbiology, School of Biological Sciences, \\ University College of Wales, Aberystwyth, Dyfed SY23 3DA
}

(Received 26 January 1977; revised I9 April 1977)

\begin{abstract}
Three classes of mutants of Escherichia coli $\mathrm{KI} 2$, isolated by selection for resistance to lipopolysaccharide-specific bacteriophages, were agglutinated by Concanavalin $\mathrm{A}$ which is presumed to interact with the lipopolysaccharide component of the outer membrane. Wheat germ and soy bean agglutinins did not agglutinate the parent or mutant strains. The adsorption of certain bacteriophages was also inhibited by Concanavalin A. The pattern of inhibition of adsorption of bacteriophages suggests that non-specific masking of receptors may occur, as well as specific masking of terminal glucose residues. Although bacteria were agglutinated by Concanavalin $\mathrm{A}$, the permeability of the outer membrane seemed unaffected.
\end{abstract}

\section{INTRODUCTION}

Plant lectins are a group of proteins which interact in a highly specific way with polysaccharides (Sharon \& Lis, 1972). Concanavalin A (Con A) is one such protein, isolated from the Jack Bean, which binds specifically to $\alpha$-linked, terminal, non-reducing D-glucose, D-mannose or $N$-acetyl-D-glucosamine residues (Goldstein \& Iyer, 1966). For precipitate formation with Con A, the polysaccharide must be branched (Goldstein, Hollerman \& Merrick, 1965; Goldstein, Hollerman \& Smith, 1965) and Con A is considered to interact with unmodified hydroxyl groups at the C-3, C-4 and C-6 positions of the pyranose ring. Wheat germ agglutinin is reported to have specificity for $\mathrm{N}$-acetylglucosamine (Biddle, Cronin \& Sanders, 1970) and soy bean agglutinin for D-galactose, although this is low relative to its specificity for $\beta$-D-galactosamine (Lis et al., 1970). Lectins have been widely and successfully used for studying the cell surface of animal cells, where they interact with glycoproteins (Nicholson, 1972a; Lis \& Sharon, 1973).

Recently, Con A has been applied to the study of the lipopolysaccharide (LPS) of Gramnegative bacteria. It has been shown to interact with multivalent polysaccharide preparations from LPS of Salmonella, Shigella and Escherichia using immunological methods (Goldstein \& Staub, 1970; Mayer, 1972; Mayer, Schlecht \& Gromska, 1975). All these polysaccharide preparations contain glucose in the $\mathrm{O}$ antigen moiety or the core region. Concanavalin $\mathrm{A}$ also interacts with the glucose or $N$-acetylglucosamine residues of the cell wall teichoic acid of certain Gram-positive bacteria, such as Bacillus subtilis and Staphylococcus aureus (Archibald \& Coapes, 1972; Doyle \& Birdsell, 1972; Birdsell \& Doyle, 1973). In these bacteria Con A has two major effects: agglutination of cells and the inhibition of adsorption of certain bacteriophages which require glucose or $N$-acetylglucosamine residues as at least a part of their receptor.

* Present address: Department of Applied Biology, School of Biological Sciences, Brunel University, Uxbridge, Middlesex.

$\dagger$ Present address: School of Science, Griffith University, Nathan, Brisbane, Queensland 4I I I, Australia. 
Since the outer core of the LPS of Escherichia coli KI2 contains glucose (Boman \& Monner, 1975; Benedetto, Bruneteau \& Michel, 1976; Prehm et al., 1976b; Picken \& Beacham, 1977), mutants in which these residues are exposed should interact with Con A. In this paper we report studies on whole cell agglutination and phage adsorption that confirm this prediction. We have also attempted to determine whether or not interaction of Con A with the LPS causes any perturbation of the outer membrane by looking for a change in permeability.

\section{METHODS}

Bacterial strains. Full descriptions and sources of the E. coli K12 parent strain ABI I57-W30, its mutant strains, strain KI060-18TI and Salmonella typhimurium TVII9 are given by Picken \& Beacham (1977). The fatty-acid auxotroph $\mathrm{K}$ 1060-2/UCB 19 is a U3-resistant mutant of KI O60-2: $\mathrm{F}^{-}$thi fabB fadE rpsL trp (Beacham \& Silbert, 1973).

Media and growth conditions. These were as described by Picken \& Beacham (1977).

Cell agglutination by lectins. Washed bacterial suspensions in $N$-2-hydroxyethylpiperazine- $N^{\prime}$-2-ethanesulphonic acid (HEPES) buffer ( $10 \mathrm{mM}, \mathrm{pH} 7 \cdot 2$ ) were equilibrated at $37^{\circ} \mathrm{C}$ and, at time zero, Con $\mathrm{A}$ (100 $\mu \mathrm{g}$ $\mathrm{ml}^{-1}$ ), wheat germ agglutinin (100 $\left.\mu \mathrm{g} \mathrm{m}^{-1}\right)$ or soy bean agglutinin $\left(500 \mu \mathrm{g} \mathrm{ml}^{-1}\right)$ was added. Controls contained no lectin or, in experiments with Con A, $100 \mathrm{mM}-\alpha$-methyl-D-glucoside ( $\alpha$-MG), a competitive inhibitor, in addition to Con A. Samples were taken at intervals and examined by phase contrast microscopy. Though some early experiments indicated that low concentrations of $\mathrm{Ca}^{2+}$ ions were necessary for agglutination (Picken \& Beacham, 1975), later experiments have shown that they are not necessary. No agglutination occurred in the presence of $\alpha$-MG. Lectins were obtained from Miles-Yeda, Rehovot, Israel, or Boehringer.

Bacteriophage adsorption. Bacteria were grown in $\mathrm{R}$ broth and harvested in the early-exponential phase (equivalent to $5 \times 10^{7}$ organisms $\mathrm{ml}^{-1}$ ). They were washed twice with $10 \mathrm{mM}$-HEPES buffer $\mathrm{pH} 7 \cdot 2$ containing the adsorption requirements of the particular phage in use: for $\mathrm{Br} 2$ adsorption, $0.01 \mathrm{M}-\mathrm{CaCl}_{2}$; for $\mathrm{T}_{4}, \mathrm{O} . \mathrm{I} \mathrm{M}-$ $\mathrm{NaCl}$; and for $\mathrm{T} 6,0 . \mathrm{I} \mathrm{M}-\mathrm{NaCl}$ and $100 \mu \mathrm{g}$ tryptophan $\mathrm{ml}^{-1}$. The bacteria were resuspended in the same buffer at a concentration of $2.5 \times 10^{8}$ organisms ml-1 and Con A was added at a range of concentrations from o to $800 \mu \mathrm{g} \mathrm{ml}^{-1}$ or, in the kinetic experiments, at I $\mathrm{mg} \mathrm{ml}^{-1}$. Controls contained $100 \mathrm{mM}-\alpha$-MG. At time zero, phage was added at a multiplicity of infection of $\mathrm{I}: 2000$. Samples were withdrawn at intervals, diluted Ioo-fold in buffer containing chloroform (Adams, 1959) and the titre of free phage was determined in duplicate. The adsorption constant, $K$, was calculated from the formula $(2 \cdot 3 / B t) \log _{10}\left(P_{0} / P_{t}\right)$ (see Adams, 1959). During these experiments the bacteria did not precipitate to the bottom of the tube, although they were observed microscopically to be agglutinated.

Enzyme release. Bacteria were grown in $\mathrm{R}$ broth, harvested in the early-exponential phase $\left(5 \times 10^{7}\right.$ organisms $\mathrm{ml}^{-1}$ ), washed three times with $10 \mathrm{mM}$-HEPES buffer $\mathrm{pH} 7.2$ containing $0.1 \mathrm{mM}-\mathrm{CaCl}_{2}$, and resuspended in this buffer at a concentration of $1.25 \times 10^{8}$ organisms $\mathrm{ml}^{-1}$. Bacterial suspensions were equilibrated at $37^{\circ} \mathrm{C}$ and Con $\mathrm{A}$ was added at $\mathrm{I} \mathrm{mg} \mathrm{ml}^{-1}$. Controls contained no Con $\mathrm{A}$ or Con $\mathrm{A}$ and $100 \mathrm{~mm}-\alpha-\mathrm{MG}$. Samples $(2 \mathrm{ml}$ ) were taken at $15 \mathrm{~min}$ intervals and centrifuged at $22500 \mathrm{~g}$ for $15 \mathrm{~min}$. The bacteria were resuspended in $2 \mathrm{ml}$ buffer, and shaken with toluene. Both bacteria and supernatants were assayed for alkaline phosphatase using $p$-nitrophenyl phosphate as substrate (Schlesinger, 1967).

Gentian violet uptake. This was carried out as described by Gustafsson, Nordström \& Normark (1973). Bacteria were pre-incubated with Con A at $1 \mathrm{mg} \mathrm{ml}^{-1}$. Controls contained no Con A.

Actinomycin D uptake. Actinomycin D uptake studies and treatment with EDTA were carried out as described by Voll \& Leive (1970). Bacteria were treated with Con A at I mg ml-1 for 15 min at $37^{\circ} \mathrm{C}$ before addition of $\left[{ }^{3} \mathrm{H}\right]$ actinomycin $\mathrm{D}\left(0 \cdot 77 \mu \mathrm{Ci} \mathrm{ml}^{-1}, 4 \mu \mathrm{g} \mathrm{ml}^{-1}\right)$.

\section{RESULTS AND DISCUSSION}

\section{Cell agglutination}

Since a uniform feature of the binding of lectins to cells is whole cell agglutination, we tested a variety of wild-type and mutant strains for agglutination (Table I). Three classes of $\mathrm{U}_{3}$-resistant mutants were agglutinated by Con A, but the parent strain was not. This is in full accord with the presence in the LPS of $E$. coli $\mathrm{KI} 2$ of three glucose residues (Benedetto et al., 1976; Prehm et al., I976b; see also Picken \& Beacham, I977). The LPS analysis and phage type of these mutant classes were reported by Picken \& Beacham (I977). It is 


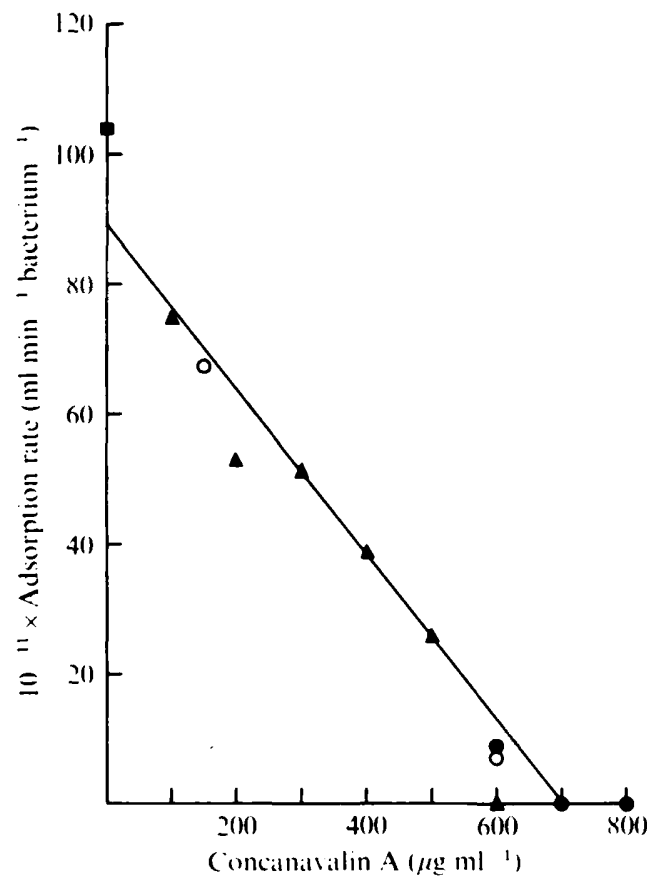

Fig. 1

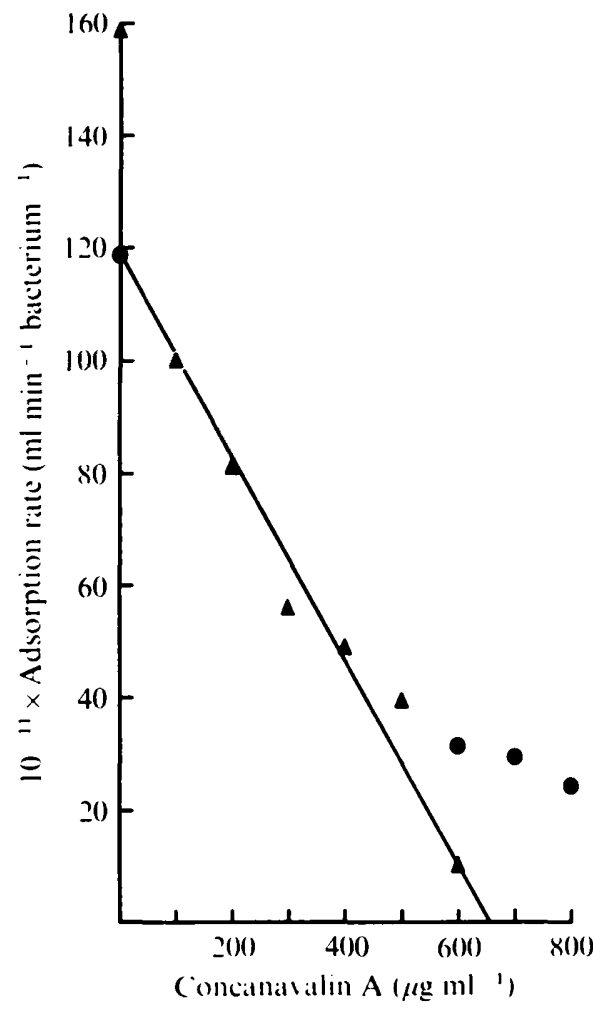

Fig. 2

Fig. I. The inhibition by Con $\mathrm{A}$ of adsorption of bacteriophage $\mathrm{Br} 2$ to the $E$. coli $\mathrm{KI} 2$ mutant strain U440. $\mathbf{}$, Average result from eight experiments. $\Delta, O, O$, Results from three different experiments.

Fig. 2. The inhibition by Con $\mathrm{A}$ of adsorption of bacteriophage Br2 to $S$. typhimurium TVII9.

$\Delta$, , Results from two different experiments.

significant that all three classes are sensitive to phage $\mathrm{Br} 2$ which optimally requires terminal glucose (or $N$-acetylglucosamine) residues as receptors (Wilkinson \& Stocker, I968; Lindberg, 1973).

Salmonella typhimurium, which has a terminal $N$-acetylglucosamine residue in its LPS core polysaccharide (Wilkinson \& Stocker, 1968), was also agglutinated by Con A but not by wheat germ agglutinin. We presume that the latter has more precise structural requirements which are not fulfilled. None of our mutants were agglutinated by wheat germ or soy bean agglutinins.

The reason for the relatively weak agglutination of strain ABII57-W3I is unknown, as is the surprising observation that another strain, KI060-I8TI, carrying the same galE allele is not agglutinated at all (Table I). Presumably the glucose III (see Fig. 2, Picken \& Beacham, 1977) residue is not exposed in a favourable manner. We have suggested that a very small number of LPS core chains of $E$. coli KI 2 terminate in galactose, attached to the glucose III residue. We presume that this galactose, together with the suggested unfavourable configuration of glucose III, results in the parent strain AB I I 57-W3O not being agglutinated.

The work of Mayer et al. (1975) suggested that phosphate groups linked to the heptose residues hinder interaction with Con $A$. This may account for the fact that mutants $\mathrm{U} 2$ and $\mathrm{T} 4235$, both of which we postulate to have a terminal glucose I residue like UIO20, were not agglutinated; in addition to the proximity of any phosphate groups, the proximity of the 

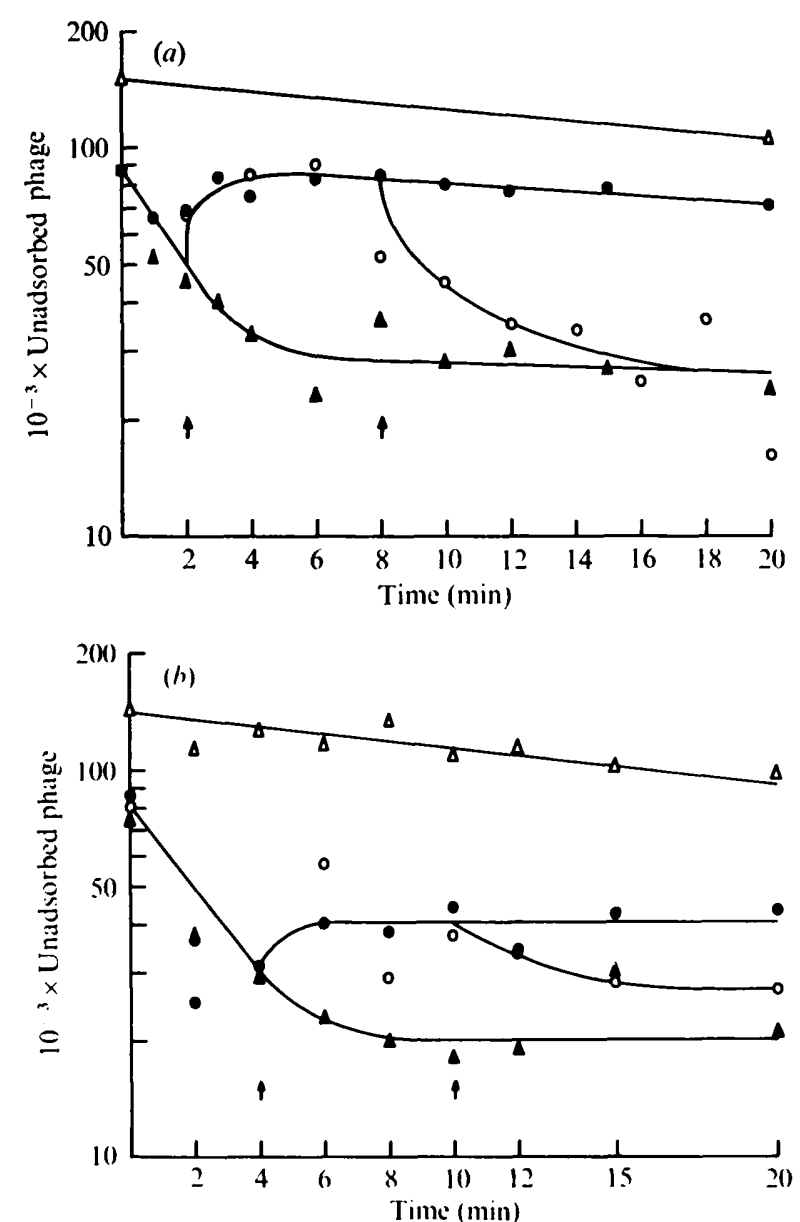

Fig. 3. The effect of Con $\mathrm{A}$ on the kinetics of bacteriophage $\mathrm{Br} 2$ adsorption to whole cells of $E$. coli K12 mutant strain U440. $\triangle$, Cells pre-incubated with Con $A$ for $15 \mathrm{~min}$, to block all adsorption sites, before addition of $\mathrm{Br2}$. $\triangle$, Adsorption of $\mathrm{Br} 2$ to untreated cells. $\mathcal{Q}$, Con $\mathrm{A}$ added to adsorption mixture at (a) $2 \mathrm{~min}$ or (b) $4 \mathrm{~min}$. $\bigcirc$, Con A added to adsorption mixture at (a) $2 \mathrm{~min}$ or (b) $4 \mathrm{~min}$, and $\alpha$-MG added 6 min later.

postulated heptose side-chain may cause steric hindrance, as it seems to in the case of phage attachment.

\section{Bacteriophage adsorption}

Phage $\mathrm{Br} 2$ requires terminal glucose (or $N$-acetylglucosamine) residues in the LPS for adsorption to $S$. typhimurium (Wilkinson \& Stocker, 1968). The observation that strain $\mathrm{U} 440$ is both sensitive to $\mathrm{Br} 2$ and agglutinated by Con $\mathrm{A}$ is consistent with this conclusion. It would therefore be anticipated that adsorption of $\mathrm{Br} 2$ to $\mathrm{U} 440$ would be prevented by Con A, through masking of the required glucose residues. Our results (Fig. I) demonstrate that Con A does block the adsorption of $\mathrm{Br} 2$ to U440, and increasing concentrations of Con $\mathrm{A}$ caused a corresponding decrease in the rate of adsorption. A Con A concentration of $700 \mu \mathrm{g}$ $\mathrm{ml}^{-1}$ was sufficient to prevent adsorption completely. Figure 2 shows the results of similar experiments using the $S$. typhimurium strain TVII9. Addition of I $\mathrm{mg} \mathrm{Con} \mathrm{A} \mathrm{ml}^{-1}$ at $2 \mathrm{~min}$ to an adsorption mixture of $\mathrm{Br} 2$ and $\mathrm{U} 440$ caused not only the cessation of adsorption but also desorption of all previously adsorbed phage (Fig. $3 a$ ); subsequent addition of $\alpha$-MG caused resorption to occur. Addition of Con $A$ at 4 min produced the same qualitative effect, except that not all the adsorbed phage were desorbed (Fig. $3 b$ ). We interpret this to 
Table I. Agglutination by lectins

All mutant classes are described in Picken \& Beacham (1977), and are derived from ABI I 57-W30. Two to four strains from each class were tested as described in Methods. Agglutination of u440 and $A B I I 57-W_{3} I$ was apparent within $5 \mathrm{~min}$ and maximal within $20 \mathrm{~min}$, whereas agglutination of U1020 usually took about three times as long. Strains of mutant classes 9 to I 2 , including T4235, were also not agglutinated by Con $\mathbf{A}$.

$\begin{array}{cl}\text { Class } & \text { Strain } \\ & \text { TVII9 } \\ \text { I } & \text { ABI I57-W30 } \\ 2 & \text { ABI 157-W3 } \\ & \text { K1 1060-18TI } \\ 3 & \text { U440 } \\ 4 & \text { U2 } \\ 5 & \text { U1020 } \\ 6 & \text { U110 } \\ 7 & \text { C35 }\end{array}$

$\begin{array}{ccc}\text { Con A } & \text { WGA } & \text { SBA } \\ +++ & - & - \\ - & - & - \\ ++ & \text { NT } & \text { NT } \\ - & - & - \\ +++ & - & - \\ - & - & - \\ +++ & - & - \\ - & - & - \\ - & \text { NT } & \text { NT }\end{array}$

+ to ++++ , Approximate indication of clump formation; - , no clump formation; NT, not tested.

* Con A, Concanavalin A; WGA, wheat germ agglutinin; SBA, soy bean agglutinin.

\section{Table 2. Adsorption rates of bacteriophages Br2, T4 and T6 to E. coli strain $\mathrm{U} 440$}

Results show the rate of adsorption as a percentage of the rate in the absence of Con A.

\begin{tabular}{lcc} 
& \multicolumn{2}{c}{ Adsorption rate with Con A at: } \\
Phage & $\overbrace{500 \mu \mathrm{g} \mathrm{ml}^{-1}}$ & I $\mathrm{mg} \mathrm{ml}^{-1}$ \\
Br2 & 23.9 & 7.2 \\
T4 & 89.5 & 15.8 \\
T6 & 73.0 & 23.4
\end{tabular}

mean that between 2 and 4 min the adsorbed phages change from a state of reversible to irreversible adsorption.

The effects of Con A on the adsorption of phage T6, which requires an outer-membrane protein receptor for adsorption (Michael, I968; Verkleij, Lugtenberg \& Ververgaert, 1976; Manning \& Reeves, 1976), and on phage T4, which requires terminal or non-terminal LPS glucose (Prehm et al., 1976a; Picken \& Beacham, 1977), are shown in Table 2. Con A inhibited the adsorption of $\mathrm{T}_{4}$ and $\mathrm{T} 6$ to $\mathrm{U} 440$ but to a lesser extent than phage Br2. The difference between the effect of Con $\mathrm{A}$ on $\mathrm{Br} 2$ and on $\mathrm{T} 4$ and $\mathrm{T} 6$ is particularly marked at $500 \mu \mathrm{g}$ Con A ml-1. Adsorption of phage T6 to ABI I57-W30, which is not agglutinated by Con $\mathrm{A}$, was only reduced to $6 \mathrm{I} \%$ by $\mathrm{I} \mathrm{mg} \mathrm{Con} \mathrm{A} \mathrm{ml}^{-1}$ (data not shown); the reduction may nevertheless indicate the presence of some glucose exposed at the surface of this parental strain which reacts with Con $A$, though insufficiently to cause cell agglutination.

The inhibition by Con A of the adsorption of phage T6 to strain U440, albeit to a lesser extent than $\mathrm{Br} 2$, indicates that some non-specific masking of receptors by $\mathrm{Con} \mathrm{A}$ might occur. In other words, the binding of Con A to glucose residues prevents adsorption of a glucose-specific phage $(\mathrm{Br} 2)$ and seems to render other receptors less available to certain phages, perhaps by steric hindrance. Phage $\mathrm{T}_{4}$ may also be only sterically hindered. But since this phage requires LPS glucose for its adsorption (Hattman \& Fukasawa, 1963; Dawes, 1975; Prehm et al., 1976a), it is surprising that it is relatively unaffected by Con A in its adsorption to strain $\mathrm{U} 440$, compared with phage $\mathrm{Br} 2$. If the initial adsorption of phage $T_{4}$ is via the long tail fibres (Simon \& Anderson, 1967; Wilson, Luftig \& Wood, 1970), these may be better able to interact with glucose residues within the LPS, in the presence of Con A, than the capsid spikes of $\mathrm{Br} 2$ which is an icosahedral phage. Another possible explanation 


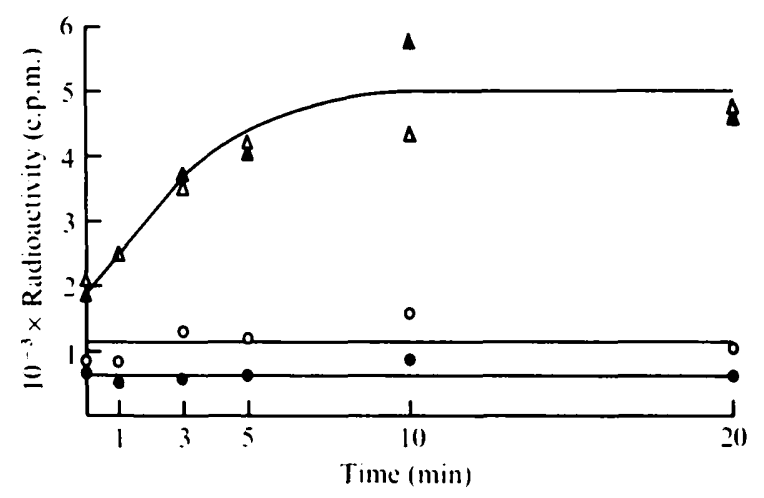

Fig. 4. The effect of Con $A$ on the uptake of [ $\left.{ }^{3} \mathrm{H}\right]$ actinomycin $D$ by EDTA-treated and untreated cells of $E$. coli $\mathrm{KI} 2$ mutant strain U440: $O$, untreated; $O$, treated with Con A; $\Delta$, treated with EDTA; $\triangle$, treated with EDTA and Con A.

may be that phage $\mathrm{T}_{4}$ and Con $\mathrm{A}$ interact with different carbon atoms of the same glucose molecule.

It has recently been reported that Con A blocks adsorption of phage $\mathrm{T}_{4}$ to $E$. coli $\mathrm{B}$ (Watanabe, 1976), a strain in which a glucose residue is terminal in the LPS (Prehm et al., I976a). A higher concentration of Con A $\left(6 \mathrm{mg} \mathrm{ml}^{-1}\right)$ was used than in the present study.

\section{Cell agglutination using a fatty-acid auxotroph}

Agglutination of animal cells by Con A is associated with a change in the topographic distribution (clustering) of Con A binding sites (Nicolson, 1972 $a, b$ ). Such clustering of the binding sites necessarily entails movement in a fluid membrane, and the data indicate that clustering is necessary for agglutination to occur. In an attempt to determine if the same situation pertains in the outer membrane of $E$. coli, strain K1060-2/UCB19 (a fatty-acid auxotroph which is agglutinated by $\mathrm{Con} A$ ) was grown with a cis $\mathrm{C}_{18: 1}$ fatty acid (oleic acid) or a trans $\mathrm{C}_{18: 1}$ fatty acid (elaidic acid) as its fatty acid supplement. The transition temperatures of phospholipids containing these fatty acids are approximately 15 and $37^{\circ} \mathrm{C}$ respectively (Overath et al., 1971). Bacteria grown on oleate or elaidate were thus incubated at $\mathrm{IO}$ and $39{ }^{\circ} \mathrm{C}$ and Con $\mathrm{A}$ was added as before. Both the oleate- and elaidate-grown bacteria agglutinated with Con $A$ at both the high and low temperatures. These results suggest that there is no requirement for clustering of Con $\mathbf{A}$ binding sites in order to produce agglutination, but do not indicate whether or not clustering occurs.

Horwitz, Hatten \& Burger (1974) have done similar experiments with animal cells. In contrast to our results they found that growth with elaidate increased, and oleate decreased, the thermal transition temperature for Con A agglutination; below the transition temperature for agglutination ( 26 to $28^{\circ} \mathrm{C}$ for elaidate-grown bacteria), little agglutination was observed.

\section{Possible membrane damage by Con $A$}

LPS profoundly influences, directly or indirectly, the permeability of the outer membrane since loss by mutation or by EDTA treatment increases permeability (Leive, 1974; Boman, Nordström \& Normark, 1974; Nikaido, 1976). Thus if LPS molecules are mobile within the outer membrane, as newly synthesized molecules are (Mühlradt et al., 1974; Bayer, 1975; Kulpa \& Leive, 1976), Con A might cause 'clustering' of LPS resulting in areas of membrane depleted of LPS, which might, in turn, result in greater permeability.

We considered the effect of Con A on leakage of a large molecule, alkaline phosphatase. through the outer membrane from the periplasm, and the effect on permeability to relatively small molecules such as Gentian violet and actinomycin D. No appreciable leakage 
of alkaline phosphatase, in excess of that of the controls, was caused by Con A attachment (data not shown). Similarly, with Gentian violet, we observed type I uptake (Gustafsson et al., 1973) in both controls and Con A-treated cells, but Con A did not appear to cause any type II uptake (data not shown). In studies on the entry of actinomycin D into the cell (Fig. 4), treatment with EDTA caused uptake, as demonstrated by Voll \& Leive (1970), but Con A had no effect on either EDTA-treated or untreated cells. No attempt has yet been made to establish directly whether clustering of LPS occurs, but these results can be interpreted to indicate that it does not.

Concanavalin A may be useful in the purification of LPS from the mutant strains of E. coli $\mathrm{K} 12$ reported here, by affinity chromatography using Con A-Sepharose, a technique successfully used for the purification of teichoic acids (Doyle, Birdsell \& Young, 1973). This possibility is of particular interest in view of the characterization of protein covalentlylinked to the LPS of $E$. coli by Wu \& Heath (I973).

We would like to thank the many people who have generously contributed bacterial strains and bacteriophages. These include Drs H. Brandis, K. Paigen, G. Schmidt and B. A. D. Stocker. R.N.P. is grateful to the Science Research Council for a Research Studentship.

\section{REFERENCES}

ADAMS, M. H. (1959). Bacteriophages. New York \& London: Wiley-Interscience.

ARChibald, A. R. \& CoAPES, H. E. (1972). Blocking of bacteriophage receptor sites by Concanavalin A. Journal of General Microbiology 73, 581-585.

BAYER, M. E. (1975). Role of adhesion zones in bacterial cell surface function and biogenesis. In Membrane Biogenesis, pp. 393-427. Edited by A. Tzagloff. New York: Plenum Publishing Corporation.

Beacham, I. R. \& Silbert, D. F. (I973). Studies on the uridine diphosphate-galactose:lipopolysaccharide galactosyltransferase reaction using a fatty acid mutant of Escherichia coli. Journal of Biological Chemistry 248, 5310-5318.

Benedetto, J. P., Bruneteau, M. \& Michel, G. (1976). Etude du lipopolysaccharide de Escherichia coli KI 2 CR34. European Journal of Biochemistry 63, 313-320.

Biddle, F., Cronin, A. P. \& Sanders, F. K. (1970). The interaction between wheat germ agglutinin and receptors on normal and transformed cells and on erythrocytes. Cytobios 2, 9-17.

Birdsell, D. C. \& Doyle, R. J. (1973). Modification of bacteriophage 25 adsorption to Bacillus subtilis by Concanavalin A. Journal of Bacteriology 113 , 198-202.

Boman, H. G. \& MonNer, D. A. (1975). Characterization of lipopolysaccharides from Escherichia coli $\mathrm{K} 12$ mutants. Journal of Bacteriology 121, 455-465.

Boman, H. G., Nordström, K. \& Normark, S. (1974). Penicillin resistance in Escherichia coli $\mathrm{K}$ I 2 : synergism between penicillinases and a barrier in the outer part of the envelope. Annals of the New York Academy of Sciences 235, 569-586.

DAwES, J. (1975). Characterization of the bacteriophage $\mathrm{T}_{4}$ receptor site. Nature, London 256, 1 27-1 28 .
DOYLE, R. J. \& Birdsell, D. C. (1972). Interaction of Concanavalin A with the cell wall of Bacillus subtilis. Journal of Bacteriology 109, 652-658.

Doyle, R. J., Birdsell, D. C.\& YounG, F. E. (1973). Isolation of the teichoic acid of Bacillus subtilis I 68 by affinity chromatography. Preparative Biochemistry 3, I 3-18.

GOLDSTEIN, I. J. \& IYER, R. N. (1966). Interaction of Concanavalin $A$, a phytohaemagglutinin, with model substrates. Biochimica et biophysica acta 121, $197-200$.

Goldstein, I. J. \& Staub, A. M. (1970). Interaction of Concanavalin A with polysaccharides of Salmonella. Immunochemistry 7, 31 5-319.

Goldstein, I. J., Hollerman, C. E. \& Merrick, J. M. (1965). Protein-carbohydrate interaction. I. The interaction of polysaccharides with Concanavalin A. Biochimica et biophysica acta 97, 68-76.

Goldstein, I. J., Hollerman, C. E. \& Smith, E. E. (1965). Protein-carbonhydrate interaction. II. Inhibition studies on the interaction of Concanavalin A with polysaccharides. Biochemistry 4, 876-883.

Gustafsson, P., Nordström, K. \& Normark, S. (I973). Outer penetration barrier of Escherichia coli K12: kinetics of the uptake of gentian violet by wild type and envelope mutants. Journal of Bacteriology 116, 893-900.

Hattman, S. \& Fukasawa, J. (1963). Host induced modification of T-even phages due to defective glucosylation of their DNA. Proceedings of the National Academy of Sciences of the United States of America 50, 297-299.

Horwitz, A. F., Hatten, M. E. \& Burger, M. M. (1974). Membrane fatty acid replacements and their effect on growth and lectin induced agglutinability. Proceedings of the National Academy of Sciences of the United States of America 71, 31 1 5-31 19. 
KuLPA, C. F. \& Leive, L. (1976). Mode of insertion of lipopolysaccharide into the outer membrane of Escherichia coli. Journal of Bacteriology x26, 467477.

LEIVE, L. (1974). The barrier function of the gram negative envelope. Annals of the New York Academy of Siciences 235, 109-1 27.

LINDBERG, A. A. (1973). Bacteriophage receptors. Annual Review of Microbiology 27, 205-24I.

Lis, H. \& Sharon, N. (1973). The biochemistry of plant lectins (phytohaemagglutinins). Annual Review of Biochemistry 42, 54I-574.

Lis, H., Sela, B. A., Sachs, L. \& Sharon, N. (1970). Specific inhibition by $N$-acetyl-D-galactosamine of the interaction between soy bean agglutinin and animal cell surfaces. Biochimica et biophysica acta 211, 582-585.

ManNing, P. \& ReEves, P. (1976). Outer membrane of Escherichia coli KI 2: $t s x$ mutants (resistant to bacteriophage T6 and colicin $K$ ) lack an outer membrane protein. Biochemical and Biophysical Research Communications 71, 466-471.

MAYER, H. (1972). Reaktivităt und Differenzierung der kompletten enterobakteriellen R-basal Typen mit Concanavalin A. Zentralblatt für Bakteriologie, Parasitenkunde, Infektionskrankheit und Hygiene (Abteilung I, Originale) 220, 477-483.

MAYer, H., SChlecht, S. \& GromsKa, W. (1975). Reactivity of lipopolysaccharides from various Salmonella SR and $\mathbf{R}$ (chemotypes $\mathrm{Ra}-\mathrm{Re}$ ) mutants with Concanavalin A. Zentralblatt für Bakteriologie, Parasitenkunde, Infektionskrankheit und Hygiene (Abteilung I, Originale) 233, 327-334.

Michael, J. G. (1968). The surface antigens and phage receptors in Escherichia coli в. Proceedings of the Society for Experimental Biology and Medicine 128, 434-438.

Mühlradt, P. F., Menzel, J., Golecki, J. R. \& SPETH, V. (1974). Lateral mobility and surface density of lipopolysaccharide in the outer membrane of Salmonella typhimurium. European Journal of Biochemistry 43, 533-539.

Nicolson, G. L. (1972a). Topological studies on the structure of cell membranes. In Membrane Research, Proceedings of the 1972 California Membrane Conference, pp. 53-70. Edited by C. F. Fox. New York: Academic Press.

Nicolson, G. L. (1972b). Topography of membrane Concanavalin A sites modified by proteolysis. Nature New Biology 239, 193-197.

NIKAIDO, H. (1976). Outer membrane of Salmonella typhimurium. Transmembrane diffusion of some hydrophobic substances. Biochimica et biophysica acta 433, II 8-1 32.

Overath, P., Schairer, H-U., Hill, F. F. \& LAMNEK-HiRSCH, I. (1971). Structure and function of hydrocarbon chains in bacterial phospholipids. In The Dynamic Structure of Cell Membranes. pp. 149-164. Edited by D. F. H. Wallach and H. Fischer. Berlin: Springer-Verlag.
Picken, R. N. \& Beacham, I. R. (I975). The interaction of Concanavalin A with mutant and wildtype strains of Escherichia coli K12. Transactions of the Biochemical Society 3, 387-388.

Picken, R. N. \& Beacham, I. R. (1977). Bacteriophage-resistant mutants of Escherichia coli KI2. Location of receptors within the lipopolysaccharide. Journal of General Microbiology 102, 305318.

Prehm, P., Jann, B., Jann, K., Schmidt, G. \& STIRM, S. (1976a). On a bacteriophage $T_{3}$ and T4 receptor region within the cell wall lipopolysaccharide of Escherichia coli B. Journal of Molecular Biology 101, 277-28I.

Prehm, P., Stirm, S., Jann, B., JanN, K. \& Boman, H. G. $(1976 b)$. Cell wall lipopolysaccharides of ampicillin-resistant mutants of Escherichia coli KI 2. European Journal of Biochemistry 66, 369377.

SCHLESINGER, M. J. (1967). Formation of a defective alkaline phosphatase subunit by a mutant of Escherichia coli. Journal of Biological Chemistry 242, I604-I6I I.

SHARON, N. \& LIS, H. (1972). Lectins: cell-agglutinating and sugar-specific proteins. Science 177, 949-959.

Simon, L. D. \& ANDerson, T. F. (1967). The infection of Escherichia coli by $\mathrm{T}_{2}$ and $\mathrm{T}_{4}$ bacteriophages as seen in the electron microscope. I. Attachment and penetration. Virology 32, 279297.

Verkleis, A. J., Lugtenderg, E. J. J. \& VerverGAERT, P. H. J. TH. (1976). Freeze etch morphology of outer membrane mutants of Escherichia coli KI 2. Biochimica et biophysica acta 426, 581586.

VoLL, M. J. \& LEIVE, L. (1970). Release of lipopolysaccharide in Escherichia coli resistant to the permeability increase induced by ethylenediaminetetraacetate. Journal of Biological Chemistry 245, I 1 108-III 4.

WATANABE, T. (I976). Role of lipopolysaccharide in adsorption of coliphage $\mathrm{T}_{4} \mathrm{D}$ to Escherichia coli B. Canadian Journal of Microbiology 22, 745-75I.

Wilkinson, R. G. \& STOCKeR, B. A. D. (1968). Genetics and cultural properties of mutants of Salmonella typhimurium lacking glucosyl or galactosyl lipopolysaccharide transferase. Nature, London 217, 955-957.

Wilson, J. H., LufTIG, R. B. \& WoOD, W. B. (1970). Interaction of bacteriophage $\mathrm{T}_{4}$ tail fibre component with a lipopolysaccharide fraction from Escherichia coli. Journal of Molecular Biology 5I, 423-434.

Wu, M.C. \& Heath, E. C. (1973). Isolation and characterization of lipopolysaccharide protein from Escherichia coli. Proceedings of the National Academy of Sciences of the United States of America 7o, 2572-2576. 